In the second trial (25 sows) PMSG and HCG were injected at intervals of 4 days, either $D_{1}$ and $D_{5}$ or $D_{2}$ and $D_{6}$.

Delay in the moment of injections did not bring about any positive effect.

\title{
SYNCHRONISATION DE L'ESTRUS DES TRUIES NULLIPARES PAR EMPLOI D'IMPLANTS DE NORÉTHANDROLONE
}

\author{
F. MARTINAT, F. du MESNIL du BUISSON et P. MAULÉON \\ Station de Physiologie de la Reproduction, \\ Centre de Recherches de Tours, I. N. R. A., \\ Nouzilly 37380 Monnaie
}

\section{RÉSUMÉ}

$8_{4}$ truies nullipares cycliques Large White ou Large White $\times$ Landrace ont reçu un ou deux implants sous-cutanés contenant chacun $25^{\circ} \mathrm{mg}$ de norethandrolone. Le progestagène (I $7 \alpha$ éthylI9 Nortestostérone) est lié à un polymère hydrophile de l'acide métacrylique (hydron).

Les implants sont retirés au bout de 20 jours. Deux à sept jours après le retrait, on constate l'œstrus pour 66,6 et 80,9 p. Ioo des truies ayant eu un ou deux implants.

Le pourcentage de truies gestantes par rapport aux truies venues en œstrus est de $45, \circ \mathrm{p}$. Ioo et de 70,6 p. Ioo respectivement. Une injection de I ooo UI de PMSG le lendemain du retrait de l'implant a eu un effet dépressif sur le pourcentage de truies gestantes. Le taux d'ovulation ( 7,4 à 19,2) est fort dans tous les lots et le nombre d'embryons à 30 jours de gestation est normal (10,2 à I 2,6 ).

La taille des implants $(9 \mathrm{~cm})$ est probablement la cause des pertes nombreuses d'implants.

D'autres essais sont nécessaires pour obtenir un groupage de l'œestrus permettant une insémination artificielle à jour prédéterminé.

\section{SUMMARY}

\section{OESTRUS SYNCHRONIZATION OF NULIIPAROUS SOWS BY IMPLANTS OF NORETHANDROLONE}

84 cyclic nulliparous Large White or Large White $\times$ Landrace sows received one or two subcutaneous implants of $250 \mathrm{mg}$ norethendrolone. The progestagen ( 7 alpha ethyl. I9 nortestosterone) is bound to a hydrophile polymere of metacrylic acid (hydron).

The implants were withdrawn after 20 days. Two to seven days after, return to oestrus was noticed for 66.6 and 80.9 p. Ioo of the sows with one or two implants.

Percentage of pregnant sows compared with sows returned to ostrus was 45.0 and $70.6 \mathrm{p}$. Io respectively. Injection of $I$ ooo IU PMSG the day after the withdrawal of the implant caused fall in the percentage of pregnant sows. The ovulation rate $(17.4-19.2)$ was high in all the groups and the number of embryos after 30 days of gestation was normal (I0.2 - I 2.6). 
Many implants were lossed probably because of their size $(9 \mathrm{~cm})$.

Further trials would be necessary to obtain blocking of ostrus allowing artificial insemination on a predetermined day.

\title{
INDUCTION D'UNE GESTATION PENDANT LA LACTATION CHEZ LA TRUIE
}

\author{
F. MARTINAT, C. LEGAULT* et F. du MESNIL du BUISSON \\ Station de Physiologie de la Reproduction, \\ Centre de Recherches de Tours, I. N.R. A., \\ Nouzilly 37380 Monnaie \\ * Station de Génétique quantitative et appliquée, \\ Centre national de Recherches zootechniques, I. N. R. A., \\ 78350 Jouy en Josas
}

\section{RÉSUMÉ}

Les truies de deux troupeaux, Large White pour l'un, Piétrain pour l'autre, ont subi une

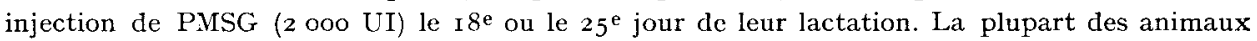
ont été traités au cours de deux lactations successives. La parités des truies étaient variables; le sevrage des porcelets a eu lieu $2 \mathrm{I}$ ou $3 \mathrm{I}$ jours après le traitement.

Sur I I I femelles traitées, 8 I ont manifesté un cestrus pendant la lactation soit, $72 \mathrm{p}$. Ioo dont 62 p. $100 \mathrm{le}_{4}$ et le $\mathrm{J}_{5}$ ( $\mathrm{J}_{0}$ étant le jour de l'injection). Dans le troupeau Piétrain, le taux d'cestrus induit diminue significativement lors du deuxième traitement.

37 p. roo des truies traitées ont mis bas à la suite d'une ovulation induite au cours de la lactation. Le nombre moyen de porcelets de ces portées est de 9,4 contre 10,4 pour les portées des truies fécondées après le sevrage (différence non significative). On constate une chute importante quoique non significative de la prolificité dans le troupeau Large White entre le premier et le second traitement.

Grâce à la relative constance de l'intervalle entre le traitement de l'apparition de l'œstrus, cette méthode est susceptible de faciliter l'utilisation de l'insémination artificielle.

\section{SUMMARY}

\section{INDUCTION OF PREGNANCY DURING LACTATING IN THE SOW}

Sows from two herds, the one Large White and the other Piétrain, received injection of PMSG ( 2 ooo IU) on day 18 or 25 of lactation. Most of the animals were treated during two successive lactations. The parities of the sows varied. Weaning of piglets occured 21 or $3 x$ days after treatment. 